\title{
Nutrisi Parenteral Total pada Bayi Prematur
}

\author{
Widiasa, Suandi, I. Wayan Retayasa \\ Bagian/SMF Ilmu Kesehatan Anak, Fakultas Kedokteran Universitas Udayana/RS Sanglah \\ Denpasar
}

\begin{abstract}
Abstrak. Dengan makin pesatnya perkembangan bidang perinatologi, makin banyak bayi kecil yang terselamatkan. Pemberian nutrisi pada bayi prematur merupakan suatu tantangan, karena nutrisi yang didapat langsung dari plasenta kini harus diberikan peroral. Pemberian nutrisi parenteral total (NPT) ataupun nutrisi parenteral parsial (NPP), merupakan sarana utama dalam perawatan bayi prematur. Pemberian NPT dapat dilakukan melalui jalur perifer atau sentral sesuai dengan kondisi bayi. Larutan nutrisi parenteral yang diberikan harus mengandung glukosa, protein, lemak dan multivitamin. Monitoring yang ketat harus dilakukan secara periodik dan berkala untuk mengindari komplikasi baik mekanik, metabolik, ataupun infeksi (Sari Pediatri 2007; 9(10):39-43).
\end{abstract}

Kata kunci: nutrisi parentral total, bayi prematur

$\mathrm{P}$ emberian nutrisi parenteral total (NPT) pertama kali diperkenalkan sejak tahun 1960 telah banyak membantu penderita pasien, terutama bayi dengan prematur. Perbaikan dalam teknik pemasangan, penggunaan alat dan komposisi makan yang lebih baik mengurangi berbagai komplikasi yang sering diakibatkan oleh NPT seperti infeksi dan gangguan metabolik. ${ }^{1}$ Dengan makin pesatnya perkembangan bidang perinatologi, makin banyak bayi dengan prematur yang terselamatkan. Di negara berkembang, angka kematian bayi dengan prematur sangat menurun hingga mencapai $5 \%$.

\footnotetext{
Alamat korespondensi:

Dr. I Wayan Retayasa, Sp.A(K).

Bag/SMF Ilmu Kesehatan Anak FK UNUD/RS Sanglah Denpasar Jl. Pulau Nias Denpasar Bali. Telepon/Fax: 0361-244038 atau 0361-257387
}

Pemberian nutrisi pada bayi-bayi dengan prematur merupakan suatu tantangan, karena nutrisi yang sebelumnya didapatkan langsung dari plasenta ibu kini harus diberikan peroral. ${ }^{1,2}$

Perkembangan nutrisi setelah lahir sangat tergantung pada keadaan maturitas dan berat badan lahir. Pada bayi prematur dengan berat lahir sangat rendah (BLSR), pemberian nutrisi parenteral harus diberikan sebelum pemberian makanan secara enteral dapat diberikan dengan baik. Pemberian nutrisi parenteral baik secara total (NPT) ataupun nutrisi parenteral parsial (NPP), telah merupakan sarana penunjang utama dalam perawatan, bahwa $80 \%$ unit perawatan intensif memberikan NPT pada minggu pertama perawatan bayi prematur. ${ }^{1,2,3}$ Pemberian nutrisi untuk bayi prematur memerlukan ketrampilan dan perawatan yang khusus untuk mendapatkan kalori dan cairan yang adekuat, mencegah terjadinya aspirasi 
dan komplikasi. Problem yang didapatkan dengan pemberian makanan secara enteral adalah reflek menghisap dan menelan yang buruk, kebutuhan kalori yang tinggi tetapi kapasitas lambung yang kecil. Tujuan pemberian NPT untuk memberikan nutrisi yang cukup untuk menyokong pertumbuhan tanpa menyebabkan efek yang merugikan terhadap pertumbuhan dan fungsi sistem organnya.,

Pemberian nutrisi parenteral baik total maupun parsial bukanlah tindakan yang rutin dilakukan pada bayi prematur, nutrisi parenteral harus diberikan untuk pasien yang tidak mampu memenuhi kebutuhan nutrisi dengan adekuat secara enteral. ${ }^{4}$

\section{Indikasi pemberian nutrisi parenteral total}

Pemberian NPT dilakukan apabila saluran cerna tidak dapat digunakan karena malformasi intestinal, bedah saluran cerna, enterokoletis nektrotikan, distress pernafasan atau keadaan dimana saluran cerna tidak mampu melakukan fungsi digestif dan absorbsi. Sebagian besar bayi prematur dilahirkan dengan usia kehamilan <32 minggu, mereka mempunyai kebutuhan gizi yang khusus karena cepatnya laju pertumbuhan dan fungsinya yang belum matang. ${ }^{5}$ Proses pemberian nutrisi melalui oral memerlukan pengisapan yang kuat, kerjasama antara menelan dan penutupan epiglotis serta uvula dari laring maupun saluran hidung, juga gerak esiphagus yang normal. Bayi yang dilahirkan pada usia kehamilan 29-30 minggu akan mulai mengisap beberapa hari setelah lahir. Koordinasi yang baik antara mengisap dan menelan biasanya tidak tampak sampai usia kehamilan 33-34 minggu. 2,4,6 Memberikan nutrisi yang optimal pada bayi prematur sangat penting dan menentukan keberhasilan tumbuh kembang bayi selanjutnya. Bayi yang mendapat nutrisi yang tidak adekuat akan mengalami gangguan pertumbuhan otak dan berisiko untuk kerusakan otak permanen. ${ }^{6}$

\section{Kebutuhan nutrisi pada bayi prematur}

Untuk mencapai pertumbuhan dan perkembangan bayi prematur yang optimal maka bayi harus mendapat cairan, elektrolit, kalori, lemak, vitamin dan mineral yang sesuai dengan kebutuhannya. Volume cairan ekstraseluler pada bayi prematur lebih tinggi dibandingkan dengan bayi cukup bulan. ${ }^{5,6}$ Bayi prematur pada minggu pertama sesudah lahir akan kehilangan cairan ekstraseluler dengan cepat yang menyebabkan penurunan berat badannya. Kebutuhan cairan pada bayi prematur dapat meningkat pada keadaan seperti memerlukan perawatan dengan radiant warmer, inkubator, fototerapi mengalami distres pernapasan, dan diare. Kebutuhan menurun pada keadaan bayi dirawat dengan double wallef incubator, di ruangan dengan kelembaban tinggi, atau mengalami oliguria. Penelitian pada bayi prematur dengan berat lahir sangat rendah (BLSR) 26-29 minggu kehilangan berat badan rata-rata pada minggu pertama berkisar 12\%-15\% dari berat lahir. ${ }^{7}$ Cara efektif mengurangi kehilangan cairan insensibel adalah dengan membungkus bayi, ruangan dengan kelembaban yang tinggi, dan memakai incubator. Apabila bayi dirawat dalam inkubator dengan kelembaban maksimal maka kebutuhan cairannya sama dengan bayi cukup bulan, yaitu 60-80 $\mathrm{ml} / \mathrm{kgbb} / \mathrm{hari}$, yang bertambah secara bertahap sampai $100-120 \mathrm{ml} / \mathrm{kgbb} /$ hari sesudah minggu pertama. Cairan parenteral awal dapat diberikan dekstrose 5\% atau dekstrose 10\%.,

Kebutuhan nutrisi pada neonatus diketahui bervariasi menurut berat lahir dan usia kehamilan. Bayi prematur hanya mempunyai sedikit cadangan energi karena kurangnya cadangan glikogen di bawah kulit. ${ }^{7}$ Kebutuhan energi bayi prematur dibagi menjadi dua komponen penting yaitu kebutuhan untuk pemeliharaan fungsi tubuh dan kebutuhan untuk tumbuh. ${ }^{8}$ Kebutuhan untuk pemeliharaan fungsi tubuh antara lain meliputi metabolisme basal, aktivitas otot regular suhu tubuh (spesific dynamic action), dan ekskresi. Kebutuhan energi untuk tumbuh berhubungan dengan kandungan energi dari jaringan dan tergantung pada komposisi jaringan baru yang disintesa. Pemberian energi parenteral $50 \mathrm{kkal} / \mathrm{hari}$ telah cukup untuk memenuhi kebutuhan pemeliharaan. Untuk sintesa jaringan, diperlukan 10-35 kkal/kgbb/hari, sedangkan untuk cadangan nutrien jaringan $20-30 \mathrm{kkal} / \mathrm{kgbb} / \mathrm{hari}^{8}{ }^{8}$

Sumber utama karbohidrat berasal dari glukosa. Untuk mencegah terjadinya hipoglikemia. Bayi prematur memerlukan $4-6 \mathrm{mg} / \mathrm{kgbb} /$ menit, penulis lain mengatakan pemberian dimulai dengan $5 \mathrm{mg} /$ $\mathrm{kgbb} /$ menit, kemudian ditingkatkan menjadi $14-20$ $\mathrm{mg} / \mathrm{kgbb} / \mathrm{menit}$. Ada yang memulai dengan $8-10 \mathrm{mg} /$ $\mathrm{kgbb} / \mathrm{menit}$ dan ditingkatkan menjadi $15-20 \mathrm{mg} /$ $\mathrm{kgbb} / \mathrm{menit}$. Ada yang harus diperhatikan dalam pemberian glukosa yang berlebihan menghasilkan 
hiperglikemi. Tindakan terhadap hiperglikemi adalah menurunkan kecepatan infus dan konsentrasi glukosa yang diberikan. 8,9

Pemberian protein dimulai 48 jam setelah pemberian nutrisi parenteral dan diberikan dalam bentuk asam amino sintetik. Jumlah kebutuhan protein dihitung berdasarkan estimasi kebutuhan nitrogen pada kehidupan fetus intrauterin. Fetus dengan kehamilan 28 minggu membutuhkan 350 $\mathrm{mg} / \mathrm{kgbb} / \mathrm{hari}$ nitrogen, sedangkan fetus matur membutuhkan $150 \mathrm{mg} / \mathrm{kgbb} /$ hari. Gambaran ini sama dengan asupan protein 2,2 $\mathrm{g} / \mathrm{kgbb} / \mathrm{hari}$ pada neonatus prematur. ${ }^{11,12}$ Pertumbuhan yang meningkat sesuai pertumbuhan intrauterin dengan pemberian asupan nitrogen antara $310-481 \mathrm{mg} / \mathrm{kgbb} / \mathrm{hari}$. Pertumbuhan dan retensi nitrogen lebih baik pada pemberian asupan protein $2,5 \mathrm{~g} / \mathrm{kgbb} / \mathrm{hari}$ pada bayi prematur. Pemberian yang berlebihan akan menyebabkan hiperamonemia. ${ }^{10,11}$

Pemberian lemak dapat menggunakan emulsi lemak $10 \%$ yang mengandung $10 \mathrm{~g}$ trigliserida dan $1,1 \mathrm{kkal} / \mathrm{ml}$ atau $20 \%$ yang mengandung $20 \mathrm{gram}$ trigliserida dan $2 \mathrm{kkal} / \mathrm{ml}$. $3,6,12$ Pemberian awal dimulai dengan dosisi $1 \mathrm{gram} / \mathrm{kgbb} / \mathrm{hari}$, kemudian ditingkatkan $1,5 \mathrm{gram} / \mathrm{kgbb} /$ hari sampai mencapai 3 gram/kgbb/hari. ${ }^{6,13}$ Pemberian emulsi lemak dimulai setelah pemberian dekstrosa dan asam amino dapat ditoleransi dengan baik dan pemberian emulsi lemak sebaiknya dalam 24 jam setelah pemberian dektrose dan asam amino. Untuk perkembangan otak diperlukan asam lemak rantai panjang seperti asam linoleat dan asam arakhidonat. Pada bayi prematur dan bayi berat lahir sangat rendah (BLSR) sering terjadi defisiensi asam lemak. Manifestasi klinis defisiensi asam lemak antara lain dermatitis, pertumbuhan rambut yang buruk, trombositopenia, gagal tumbuh dan mudah terjadi infeksi. Pemberian infus lemak harus dihentikan jika terjadi sepsis, trombositopenia $\left(<50.000 / \mathrm{mm}^{3}\right)$, asidosis $(\mathrm{PH}<7,25)$, dan hiperbilirubinemia. ${ }^{6,1}$

Kebutuhan vitamin dan mineral pada bayi prematur, dapat diberikan multivitamin intravena yaitu MVI-Pediatrics (Armour) yang merupakan gabungan vitamin yang larut dalam lemak dan air. Sediaan yang hanya larut dalam air, yaitu Soluvito- $N$ dapat ditambahkan pada larutan glukosa dan yang larut dalam lemak, yaitu Vitilipid-Ndapat ditambahkan pada larutan lemak. Pemberian Vitamin A dapat diberikan sejak awal, karena Vitamin A penting untuk pertumbuhan jaringan, sintesa protein, dan kerusakan epitel. Walaupun unsur mineral didalam tubuh jumlahnya sangat sedikit $(<0,01 \%)$, tetapi diperlukan untuk pertumbuhan dan perkembangan. The American Society for Clinical Nutrition menganjurkan pemberian unsur mineral setelah pemberian NPT selama 4 minggu, tetapi unsur seng dapat diberikan lebih awal. ${ }^{14,15}$

Bayi prematur mempunyai kemampuan adaptasi yang lebih rendah terhadap vitamin parenteral dibandingan bayi cukup bulan, sehingga resiko keracunan dan defisiensi lebih tinggi. Pada bayi prematur diperlukan formulasi khusus. Preparat MVI-Pediatric dengan dosis $2 \mathrm{ml} / \mathrm{kgbb} /$ hari sampai maksimum $5 \mathrm{ml} / \mathrm{kgbb} /$ hari dianggap cukup. Penambahan preparat MVI-Pediatric ke dalam emulsi lemak akan menurunkan kehilangan retinol sehingga konsentrasi retinol plasma pada bayi prematur akan meningkat.

\section{Tata laksana nutrisi parenteral}

Terdapat dua macam teknik pemberian NPT yang sudah dikenal luas, yaitu rute perifer dan rute sentral, namun pada bayi ada satu rute lagi yang bisa diberikan yaitu rute arteri umbilikalis. Pada pemberian melalui rute perifer, bisa digunakan vena di tungkai atau di kepala. Jalur ini dipilih bila pemberian dalam waktu singkat ( $<2$ minggu), osmolalitas cairan yang diberikan tidak tinggi dan tidak ada pembatasan pemberian cairan. ${ }^{2,6}$ Pada bayi pemberian melalui rute perifer sulit untuk memenuhi kebutuhan kalori karena cairan dibatasi tidak melebihi $130 \mathrm{ml} / \mathrm{kgbb} /$ hari, konsentrasi dekstrose kurang atau sama dengan 12,5\%, sehingga kalori yang dapat diberikan adalah $80 \mathrm{kkal} / \mathrm{kgbb} / \mathrm{hari}{ }^{6}{ }^{6}$ Untuk mendapatkan masukan kalori yang tinggi harus digunakan cairan infus dengan konsentrasi yang tinggi dengan risiko osmolalitas yang tinggi, lebih dari $1000 \mathrm{mmol}$ osmol/l. Ini dapat dilakukan dengan jalur vena sentral. ${ }^{6,13}$ Untuk mencapai vena sentral dapat dengan cara perkutan atau dengan cara pemotongan vena. Vena jugularis dan vena subclavia adalah yang paling sering digunakan. Cara jalur vena melalui vena subclavia tidak dianjurkan pada bayi karena sering terjadi komplikasi. Perawatan yang teratur dan berhati-hati sangat penting pada pemakaian keteter vena sentral agar terhindar dari komplikasi aman, dan dapat digunakan dalam jangka panjang. Tidak 
dibolehkan memberikan selain cairan nutrien melalui keteter ini seperti memberikan darah atau mengambil sampel darah. ${ }^{6,13}$

Pemakaian jalur arteri umbilikal masih kontroversial, sebagian setuju dan sebagian tidak. Pada kelompok yang setuju, penggunaannya praktis karena lebih mudah melakukannya, terutama pada bayi prematur dengan kecil masa kehamilan. Pada kelompok yang tidak setuju, mengemukakan alasan karena banyak terjadi trombosis aorta dan arteri iliaka, trombosis pada vena sentral serta perifer. Pada prematur dengan BLSR dapat diberikan NPT secara lengkap mulai dari hari pertama, tanpa menimbulkan efek samping dan peningkatan berat badan yang dicapai sesuai dengan pertumbuhan intrauterin. ${ }^{13}$

\section{Pemantauan}

Bayi yang mendapat NPT perlu perawatan dengan pemantauan yang ketat sehingga mereka dirawat di ruang intensif., ${ }^{5,8,8}$ Berat badan tidak naik adalah efek awal asupan kalori yang tidak adekuat. Kenaikan berat badan setiap minggu adalah standar yang dipakai untuk menentukan pertumbuhan pascanatal yang adekuat. Nutrisi yang adekuat mungkin lebih baik ditaksir dari adanya lemak di bawah kulit dan perkembangan otot. Ketebalan lemak kulit triceps digunakan untuk estimasi pertumbuhan lemak, dan lingkar atas untuk perkiraan pertumbuhan otot. Monitoring pertumbuhan minimal antara lain berat badan setiap hari, panjang badan setiap minggu, dan lingkar kepala setiap minggu. Pengukuran ini harus dicatat setiap minggu pada kurva pertumbuhan yang sesuai pada bayi prematur untuk meyakinkan pertumbuhan yang adekuat. ${ }^{8,16}$

\section{Komplikasi}

Pada kateter vena sentral dapat terjadi atrimia, efusi pleura, emboli paru dan hidrosefalus sekunder terhadap trombosis vena jugularis. Pada vena perifer, ektravasasi cairan infus dapat menyebabkan nekrosis jaringan dan deposisi kalsium pada jaringan subkutan. ${ }^{13,17}$ Sepsis sering disebabkan oleh Staphylococcus, Streptococcus viridans, Escherisia coli, Pseudomonas spp dan Candida albicans. ${ }^{13,16}$ Pada bayi berat lahir amat sangat rendah sering terjadi hiperglikemia. Hiperlikemia terjadi karena kelebihan pemberian insulin. Pada bayi kurang bulan kelebihan beban protein akan menimbulkan hiperammonia. ${ }^{(16,17)}$ Risiko terjadi hiperbilirubinemia meningkat pada bayi prematur dan pemberian NPT yang lama tanpa disertai entral feeding. Keadaan ini biasanya terjadi secara dini dan lebih berat pada keadaan pemberian protein yang tinggi dan cairan dekstrosa yang hipertonis. Kelainan metabolik yang berhubungan dengan pemberian lipid, antara lain hiperlipidemia dan hiperkolesterolnemia. ${ }^{16,17,18}$

\section{Kesimpulan}

Pemberian NPT pada bayi prematur bukanlah suatu tindakan yang rutin dilakukan. Pada prematur, diberikan NPT selama pemberian peroral belum dapat ditoleransi oleh bayi. Tindakan ini dapat menurunkan angka mortalitas. Pemberian NPT dapat dilakukan secara perifer atau sentral sesuai kondisi klinis bayi. Larutan nutrisi parenteral yang diberikan harus mengandung glukosa, protein, emulsi lemak, dan multivitamin yang optimal, sehingga tujuan dari pemberian NPT itu dapat tercapai. Monitoring yang ketat harus dilakukan secara periodik dan berkala untuk menghindari komplikasi, baik mekanik, metabolik ataupun infeksi.

\section{Daftar Pustaka}

1. Monintja HE. Prematuritas dan retardasi pertumbuhan. Dalam: Markuni AH, Pustaka Amalia, penyunting. Penanganan mutahir bayi prematur. Bagian/SMF Ilmu Kesehatan Anak FK UI Jakarta;1997.h.224-40.

2. Nelson WE. Prematurity and infra uterine growth retardation. Dalam: Behrman RE, Kliegmen RM, Arvin AM, penyunting. N Engl J Med 1993; 329:1649-52.

3. Latt SA, Fetal growth and neonatal adaptation. Dalam: Avery ME, Teusch HW, penyunting. N Engl J Med 2003; 157:593-600.

4. Hack M, Fanarat AA. Outcome of extremely immature infants:a perinatal dilemma. N Engl Med J 1998; 330:166-7.

5. Pustaka AA. Bayi dengan berat lahir rendah. Dalam: Akre J, penyunting. Pemberian makanan untuk bayi. Bagian/SMF Ilmu Kesehatan Anak FK UI Jakarta; 1990.h.127-62.

6. Paramita, Yudarta A A. Nutrion Parenteral. J Pediatrics 1999; 107:106-11. 
7. Richard, Wood NS, Gibson AS. Longitudinal growth of hospitalized very low birth wright infants. J Pediatric 1999; 104:280-89.

8. Anomin. Intensive care nursery house staff manual. Diakses pada September 6, 2004 Didapat dari URL : http:www.emro.whoint.

9. Agneti A, Aylward GP, Wright A. Glucogenesis in very low berts weight infants receiving total parenteral nutrition. J. Diabetes 1999; 48:791-800.

10. Clotilde, Casey PH. Acute effect of intravenause glutamine suplementation of protein metablism in very low birth weight infants: a stable isotope study. J Pediatrics 2002; 51:87-93.

11. Patti K, Killer C. Effect of low versus high intravenus the early neonatal period. J. Pediatrics 2002; 53:24-34

12. Brenda AH, Khalel KA, Amrawys AN. parenteral glutamine suplementation on plasma amino acid concentration in extremely low birth weight infants. J Clin Nutrition 2003; 52:43-45.
13. Sukadi A. Total nutrisi parenteral. Dalam: Rukna Suradi, Pustaka Amaka, penyunting. Buku pedoman terapi penyakit pada bayi baru lahir. Bagian/SMF Ilmu Kesehatan Anak FK UI Jakarta; 2002.h.114-24.

14. Zlotkin SH, Stalling VA, Pencharz PB. Total parenteral nutrition in children. J Pediatric Clin North Am 2002; 32:381-393.

15. Gibson LW, Wise PH. Compatibility of calcium and phosphet in for parenteral nutrition solutions for preterm neonatal. J Health-System Pharmacists 2003; 60:104-24.

16. Erika, Dvon MH. Effects of early nutrition on radical formation in VLBW infants with respiratory distress. J Am College Nutrition 2002; 19:237-41.

17. Jane RW, Wood AR, Valk AM. Role of L-carnitine in apnea of prematurty a randomaised controlled trial. J of Am Ac Pediatr 2002; 109:622-6.

18. Alaeddin KW, Shan FW, Becker TM. Total parenteral nutrition - associated cholesrasis in surgical neonates. J of Med Sci 1999; 29:689-92. 